\title{
Correction to: Short-term results of a new self-locking cementless femoral stem: a prospective cohort study of the Lima Master ${ }^{\mathrm{SL}}$
}

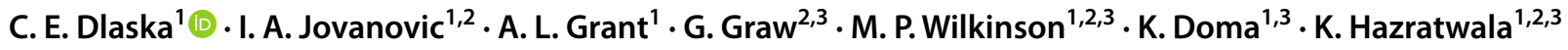

Published online: 31 December 2020

(c) The Author(s) 2020

\section{Correction to: MUSCULOSKELETAL SURGERY https://doi.org/10.1007/s12306-020-00651-1}

The article Short-term results of a new self-locking cementless femoral stem: a prospective cohort study of the Lima Master $^{\mathrm{SL}}$, written by C. E. Dlaska, I. A. Jovanovic, A. L. Grant, G. Graw, M. P. Wilkinson, K. Doma, K. Hazratwala, was originally published electronically on the publisher's internet portal on 02 March 2020 without open access. With the author(s)' decision to opt for Open Choice the copyright of the article changed on 12 December 2020 to $\odot$ The Author(s) 2020 and the article is forthwith distributed under a Creative Commons Attribution 4.0 International License, which permits use, sharing, adaptation, distribution and reproduction in any medium or format, as long as you give

The original article can be found online at https://doi.org/10.1007/ s12306-020-00651-1.

\section{E. Dlaska}

Constantin.dlaska@gmx.at

I. A. Jovanovic

Ivana.a.jovanovic@outlook.com

\section{A. L. Grant}

Research_Coordinator@oriql.com.au

G. Graw

Genevieve.graw@gmail.com

M. P. Wilkinson

mprwilkinson@outlook.com

K. Doma

Kenji.doma@jcu.edu.au

K. Hazratwala

Koshman1@me.com

1 Orthopaedic Research Institute of Queensland, 7 Turner Street, Pimlico, Townsville, QLD 4812, Australia

2 Department of Orthopaedics, Townsville Hospital, Townsville, Australia

3 James Cook University, 1 James Cook Drive, Douglas, Townsville, QLD 4814, Australia appropriate credit to the original author(s) and the source, provide a link to the Creative Commons licence, and indicate if changes were made. The images or other third party material in this article are included in the article's Creative Commons licence, unless indicated otherwise in a credit line to the material. If material is not included in the article's Creative Commons licence and your intended use is not permitted by statutory regulation or exceeds the permitted use, you will need to obtain permission directly from the copyright holder. To view a copy of this licence, visit http:// creativecommons.org/licenses/by/4.0/.

The original article has been corrected.

Open Access This article is licensed under a Creative Commons Attribution 4.0 International License, which permits use, sharing, adaptation, distribution and reproduction in any medium or format, as long as you give appropriate credit to the original author(s) and the source, provide a link to the Creative Commons licence, and indicate if changes were made. The images or other third party material in this article are included in the article's Creative Commons licence, unless indicated otherwise in a credit line to the material. If material is not included in the article's Creative Commons licence and your intended use is not permitted by statutory regulation or exceeds the permitted use, you will need to obtain permission directly from the copyright holder. To view a copy of this licence, visit http://creativecommons.org/licenses/by/4.0/.

Publisher's Note Springer Nature remains neutral with regard to jurisdictional claims in published maps and institutional affiliations. 